\title{
Diversity in a multicultural and polyethnic world: challenges and responses
}

Cornel du Toit

(University of South Africa)

\section{ABSTRACT}

\section{Diversity in a multicultural and polyethnic world: challenges and responses}

Today's world is characterised by multiculturalism. The diversity of cultures and conflicting ethnic groups sharing the same territory pose a threat to both local and world peace. We have come to the end of the 'nation' and the end of the 'state', two homogenous entities which are increasingly being emasculated by an instrumental reason in the form of techno-science and economic globalisation. Ethnic diversity is simultaneously a source of wealth and a threat to African societies. African unity in the form of an ubuntu-ethic offers a model for dealing with polyethnicity. Ethnocentrism is biologically rooted and operates through prejudice. As a coping mechanism for dealing with diversity, prejudice has its value and its limitations. It must be contained where it leads to xenophobia, ethnophobia and war. Polyethnic coexistence is a prerequisite if Africa is to attain its developmental ideals as expressed in the NEPAD programme. In this paper, I look at the way in which ethno-philosophy and ethno-theology can help this process.

\section{INSTRUMENTAL REASON ${ }^{1}$ AND THE DEATH OF SOCIETY}

Instrumental reason: Economic globalisation, technology and the death of cultural communities and cultural plurality

Global, postmodern societies are characterised by multicultural and polyethnic diversity. Gone are the ideals of unity, national self-

1 Instrumental reason is used in this article similarly to the expression: instrumental value. Some item has instrumental value to the extent that it lends itself effectively to the achievement of some desire or valued purpose. It is that which is good as a means to... In the case of instrumental reason, reason is applied to that which is purposeful and a means to...In this context, reason serves the instrument of market, technology, and consumerism, disconnected from the world of cultures, values, and meanings. 
identity, and monolithic society. Globalism ${ }^{2}$ has become the buzzword for this diversity and the symbol for the ideal of a unified world. In its current phase, globalism enabled nation-states in the West to tolerate a greater diversity within their boundaries. Most countries in the world have to deal with multiculturalism, and, depending on the context, multiculturalism may become a sociopolitical time bomb. There are no magic solutions to multicultural and polyethnic diversity.

The global flow of cultures, people, technology and commodities can neither be successfully managed nor successfully controlled. National and cultural borders are being crossed constantly. Globalism, supported by technological innovations such as information technology, communication technology, video and film, exerts a homogenising effect on society(ies). There is a worldwide reaction to the influence of mass culture and its valueintegrative effect. The influence of mass culture implies the arbitrary construction of identities constructed by ideologies outside a specific society. Increasingly, all cultures are becoming dependent on technology. Due to the inseparability of mass culture and technology, it is becoming difficult to react against mass culture. The ubiquitous presence and use of technology and instrumental reason identifies technology as the main component of mass culture. This threatens the diversity of everything produced by all cultures of the past. At the same time, the openness of the market and the demands of technology are the best defence against the threat of fundamentalist communitarianism (Touraine 2000:63,196). In today's world, instrumental reason $^{3}$ affects the whole world, especially when applied through techno-science and economic globalisation. Because technology and economy are seen as valuefree, they can supposedly be appropriated and applied anywhere in an inappropriate way. Technology, especially the development of

2 For a discussion of the paradoxes inherent in globalisation, see $\mathrm{Du}$ Toit (2002:69-71).

3 The modern scientific revolution (1500-1700) detached science and technology from wisdom, ethics and values, and interpreted scientific reason as instrumental reason, a version of reason which is allegedly value-free. The science-values separation guarantees the untouchable character of science. Similarly, instrumental reason is immune against unmanageable, global, cultural plurality (see also Moltmann 2002:27). 
communication and information technologies, made possible both global unity and global diversity, while economic globalism stresses the interdependence of all.

Our postmodern ${ }^{4}$ society brought along with it postdemocracy and postsociety. Being global citizens whose fate is determined by multinational corporations linked to neither state nor nation, queries democracy as we know it. The sovereignty of the state is challenged by economic globalisation. Mass culture brings along with it the death of society with the endless production of copies for which there is no original, where the world is endlessly duplicated through simulation in the video-sphere (world of images: television/ video/film) (see Baudrillard 1998).

Diversity in this context implies that we have lost control, that both subject and society have been decentred. Viewing the world as a global village does not shrink it to a manageable size, and regarding our culture as postmodern does not describe or fix our cultural identity.

Globalism has forced the issue of diversity on all of us. Africa is no exception. To survive economically, most countries must adhere to the principles of economic globalisation. This presupposes the absence of war and faction fighting, good infrastructure and telecommunication, a regional lingua franca, a shared view on economic targets and the acceptance of the principles enabling all of this. The NEPAD programme will have to meet these requirements in order to place Africa on the global economic map.

\section{MULTICULTURALISM}

The universal reality of multiculturalism ${ }^{5}$, and the increasing appearance of ethnocentrism, makes multiculturalism one of the foremost of all social and political problems. Few countries have a

4 For Featherstone (1995:88), postmodernism is to be regarded as 'the end of history' in the sense of the end of the belief in the overcoming of the present in pursuit of the 'new'.

5 Culture is wonderfully complex and tuned to the environment in which it has evolved. It is therefore misleading to think of culture as evolving from a lower to a higher status, and it is wrong to entertain biological explanations of cultural diversity (Wilson 1998:201). Cultural diversity is not the consequence of genetic differences, but must be related to environmental and bio-geographic factors. 
good track record in managing their multicultural reality. This is perhaps the reason why South Africa's transition to a multiparty democracy was hailed as a miracle. South African multiparty democracy includes a multicultural, polyethnic and interreligious democracy. All over the world minority groups are struggling for their rights and are responding to cultural and political domination in fundamentalist and communitarian ways, seeking identity and unity. Intrasocietal subcultures contribute to the diversification and complexification of the picture. A much more pluralistic pattern of relationships among the worlds's peoples seems to be emerging, but its form remains irregular. Bloody conflicts between religions, cultures, regions, nationalities or ethnic groups continue.

Over a relatively short period of time we have experienced, among other things, the following: the dismantling of the Soviet Union and the rekindling of nationalist passions in Central and Eastern Europe; the fall of the Berlin wall; the Serb government's policy of ethnic cleansing after the breakup of former Yugoslavia; the ethnic cleansing in Burundi; the war between Christians and Muslims in Southern Sudan; the Jewish invasion of Palestine; suicide bombers; the September 11 catastrophe; smouldering tension in the Arab world after the American invasion of Afghanistan and Iraq. These examples are related in one way or another to particular terms, such as 'tradition', 'identity', 'ideology', 'values', 'technology', 'economy', 'globalism', 'nation', 'culture', 'state' and 'people'. These terms have become distinctive in our vocabulary, and are indicative of the extent to which diversity occupies our minds (see Geertz 2000:220-221). Many, if not all, cultures are threatened by diversity and its potential to cause societal disruption, individual dislocation and cultural disintegration.

Multiculturalism is more than the expression of cultural variety. The 'problem' of multiculturalism concerns communication $^{6}$. Communication presupposes the existence not only of

6 For Geertz the public space is home to homo sapiens. In the public space, we position ourselves and form perceptions related to public images without which we literally do not know how to feel. The public space holds public imagination and sentiment - our worldview. Intra-space is the world of communication, of language raised to the level of Being. We perceive through language games, communities of discourse, intersubjective systems 
common languages, but also the existence of messages with a different content and form, the possibility of misunderstanding, and the influence of prejudice. If multiculturalism is to 'succeed' and to stimulate peaceful coexistence, then meaningful communication is a prerequisite.

Multiculturalism cannot be reduced to meaning an unrestricted pluralism. It must be defined as an attempt to establish communication between, and the partial integration of, cultural ensembles that have been separated. Communitas, rather than societas, determines society. Without the attempt of recomposition the bringing together of cultural diversity - cultural diversity can only lead to culture wars (Touraine 2000:179). With postmodernism, we find a re-emergence of the vernacular, of a playful collaging of styles and traditions. There is a return to local cultures with the emphases on local cultures in the plural, and the fact that they can be placed alongside each other without hierarchical distinction (Featherstone 1995:96). This is not to say that multi-culturalism equals either the endless fragmentation of cultural space or a worldwide, cultural melting pot. Instead, it is an attempt to reconcile the diversity of cultural experiences with the mass production and distribution of cultural goods.

Multiculturalism includes the intracultural management and support of minority rights. Minority rights for cultural, subcultural, religious and language minorities have not received proper attention. Apart from ensuring objective rights for minority groups, attention must be given to intercultural and intrasocietal relationships. Becoming acquainted with different worlds, strange customs and novel ideas is a long and cumbersome process. A hermeneutics of the Other cannot be 'learned' like the hermeneutics of a text. On a cultural level we have learned to order things in our world. We act, appreciate, detest according to our order of things. This is our value system, a system which contains strong moral convictions about what is right or wrong, good or bad, acceptable or not. We usually eschew what we do not like and avoid anticipated unpleasant encounters. Most people rather avoid being exposed to the challenge of diversity at all.

of reference, ways of worldmaking which all arise within the frame of concrete social interaction (Geertz 2000:76; Waghorne1984:50). 


\section{AFRICAN UNITY AND ETHNO-DIVERSITY}

Ethnicity (polyethnicity) is usually understood from the biological perspective of race, while multiculturalism refers to the specific culture of a people. The concept of race and ethnicity is based on the subjective belief in common descent due to similarities of physical type or custom. Culture and ethnicity help us to identify and refer to a person or ethnic group. Since a specific culture is often identified with a specific ethnic group, we have become used to associating a specific culture with a specific region, language, conduct, and customs. But, in a global world, language use, conduct and custom are seldom specific to ethnic and culture. Different ethnic and cultural groups may speak the same language, participate in the same culture and share similar customs.

The sharing of culture and custom is not the problem. The main problem with ethnicity is extreme ethnocentrism, which is manifested in xenophobic attitudes, aggression towards other groups, discrimination, extreme nationalism and patriotism and ethnic fundamentalism, leading to aggression and war. Ironically, there exists no thing such as culture ${ }^{7}$, race, or ethnicity ${ }^{8}$. These are all cultural constructions, often loaded with prejudice. A culture is an open process and can never be fixed; nor do race and ethnicity exist as biological categories.

The diversity of African cultures is often ignored. The difference between black cultures is as significant as the differences between white cultures. For many, however, there are simply too many undistinguishable ethnic groups to distinguish which ethnic identity a person belongs to. Africa is "united" simply because of the

7 For Geertz, culture is nothing at all: nothing in the mind, and nothing in behavioural patterns (Geertz 1973:44; Waghorne 1984:40).

8 What one finds in real life is not culture, race or ethnicity, but dynamic communities. Community life, however, can become absolute. This is known as communitarianism, where the collective identity of a community becomes normative. It identifies this identity with cultural practises and political power, and is a total society, intolerant to everything that is foreign. No democracy is possible in a communitarian society, since it cannot share power with any group not identical to itself (Touraine 2000:164). It identifies, in a fundamentalist way, one power with one society and one culture. White Afrikaner society under apartheid was a communitarian society. 
idea of race. Africa is black. Afro-Americans, when expressing their linkage to Africa, identify with the idea of Africa, and not with a specific African culture, ethnic group or language. African identity as black identity is the reclaiming of black in its positive sense in response to the negative connotations imposed on it by the colonial rulers. But if race does not really exist outside human perception, it is not 'blackness' that unifies Africa. 'Race' does not exist in biology. There is no evidence that 'racial' differences have a genetic basis. There is more genetic variation within races than among races, and racial categories do not capture biological distinctiveness. As in the case of racism, ethnocentrism is an attitude. Attitudes and beliefs are evolutionary, are neutral and have no strong genetic basis (Dunbar 1987:55-56).

Both natural and cultural diversity is a given. It represents the outcome of long evolutionary and cultural processes which, once destroyed and lost, cannot be regained. Natural and cultural diversity is the product of a complex interaction with the physical environment in which it developed. Seen in this light, Africa must value its cultural and ethnic diversity. From an evolutionary point of view, diversity is celebrated and respected since diversity is the successful outcome of those species that managed, over millions of years of struggle, to adapt to hostile environments. Diversity in nature is expressed in ecological balance, symbioses, and interdependence. From time to time, the cultural ecological balance of human societies is disturbed and changed by revolutions.

Africa is not one, but is divided into a plurality of ethnic groups, cultures and languages. This fact alone makes it foolish to think of Africa and refer to Africa as monolithic whole. Houtondji refers to this approach as unanimism, which describes the strange and unwarranted assumption that all the inhabitants of the vast and varied continent can be supposed to resemble each other in a salient characteristic of thought or culture (Basu 1998). As the planet's oldest continent, Africa displays one of the most diverse geographies and the largest diversity of languages, cultures, and styles of living. About 1500 languages, representing a quarter of the world's languages, are spoken in 53 African countries. No other continent even approaches this degree of human diversity (This is an average of 28 languages for each African country). This language diversity is indicative of Africa's ethnic diversity (see Diamond 1998:381-384). 
African cultural diversity is embedded in Africa's ethnic diversity. When ethnicity develops into ethnocentrism, it becomes an unpredictable force which can devastate any country. It is Africa's ethnic wars that are obstructing the NEPAD and African renaissance initiatives. Most African countries comprise several different ethnic groups and most of the wars that tortured Africa in the past and that are presently plaguing Africa are ethnically related ${ }^{9}$. Ethnic groups which lose during ethnically based multiparty elections feel that their interests are unrepresented in parliament. What are the chances that in South Africa, for example, a member from the Venda minority group such as Mr Ramaphosa, will be elected as president? Will the Xhosa ethnic group, from which the first two presidents in democratic South African were chosen, be satisfied with a president from a minority group? If democratic elections produce a majority government which is dominated by one (or a few) ethnic groups, the legitimacy of the leaders may be questioned by other ethnic minority groups, especially if there has been a history of ethnic conflict. This situation encourages rebel groups to coerce followers into armed conflict, common to many African states.

Ethnic conflicts and wars are not limited to Africa. Perhaps Africa suffers more from ethnic clashes due to its rich variety of ethnic groups. To what extent can the undesirable aspects of ethnocentrism be mastered, and how can African cultural diversity help with this task? To what extent will the NEPAD and the AU programme for African unification, Pan Africanism, the African parliament, and other agreements help Africa to cope with its ethnic diversity?

African cultures have many commonalities, as is the case with European or Eastern cultures. Similar environmental influences usually have the same effect on different cultures just as environmental differences explain the different outcome of different people and cultures $^{10}$. Africans are historically linked by the

9 It is interesting to note that, according to Silverman (1987:116), of the 277 substantial wars that have occurred throughout the world since 1945, 71 percent have been regional or civil, involving (ostensibly) people from the same ethnic population.

10 History followed different courses for different peoples because of differences among peoples' environments, not because of biological differences among peoples themselves (Diamond 1998:25). 
collective experience of colonisation and by its common history of oppression and suffering.

Just as the physical environment has the same effect on different people, cultural similarities, as well as interdependence, need and threat, can lead to the creation of similar cultural patterns such as ubuntu. African cultural unity is often typified by the idea of ubuntu. However, it would be a mistake to limit African society to ubuntu, or to restrict personal identity to communal identity. That personhood identified by an individual's interaction with other persons does not eliminate personal identity (see Louw 2002:14, 16). It simply says that my personal identity comes to the fore in my interaction with, and place in, my community. Ubuntu is an ethic that developed in a context of essential interdependence and severe need $^{11}$. Ubuntu may just as easily be discarded by urbanised and economically independent Africans. Ubuntu is easily romanticised by whites suffering from the isolation and fragmentation that comes along with individualism. Ubuntu - in the sense of caring and sharing - was not so foreign to white Afrikaners when they themselves suffered from poverty and oppression.

Ubuntu functions as a tribal, social security system. The much hailed ubuntu system must be seen in the context of a specific tribe, clan and family. Traditionally, members of the clan were dependent on each other for agriculture and general aid (Wiredu 1992:201ff). Depending on the intensity of the need, or the severity of the threat, ubuntu caring and sharing principles are applied selectively. This is in line with the acceptance of African diversity. In the words of Nyasani (quoted by Basu 1994:6) "The African's surrender to the "we" is the result of an inveterate psychological disposition largely born out of a hostile environment in which he finds himself." Basu continues that it is equally illegitimate to assume that Africa has a collective philosophy. This assumption fails to recognise Africa's diversity. He furthers distinguishes the economically based European socialism from the ethically related African communitarianism (Basu 1994:8; see also Gyekye 1992:111). The point we

11 In this regard, Hannah Arendt's refusal to reduce human experience to the domain of needs must be noted. Human needs are socially determined and cannot be the basis for freedom. This would be valid in all circumstances where extreme interdependence determines individual action (see Touraine 2000:132). 
wish to stress is not that African society is predominantly collective, but that the African person should not be limited to collectivity, anymore than a Western person can be restricted to individualism. There is a right to live beyond one's culture, on the border of cultures, to take a step transcending one's own surroundings, one's native culture and one's milieu. This constitutes no betrayal, because the limits of any culture are too narrow for the full range of human potential.

\section{PREJUDICE IN MULTICULTURALISM AND ETHNO- CENTRISM}

\section{Ethnocentrism as a cultural construction and the natural determination based on biological roots}

We have to acknowledge that we are all ethnically bound in one way or another. It is part of our evolutionary makeup. Should ethnocentrism be stated as an ideal to be eliminated? Ethnocentrism is usually defined as a belief in the superiority of one's own group or race. Ethnocentrism is a loose cluster of traits which predispose the individual to show discriminatory preferences for members of groups with closest affinities to the self (Vine 1987:60). In extreme forms, this usually involves the explicit belief that members of the 'out-group' are morally or biologically inferior (Dunbar 1987:55).

The sociobiology of intergroup relations assumes that human beings lived, for most of the time, in small groups with kinship connections within and between groups. Discrimination against strangers, in favour of kin, would be akward because cohesive kin groups had a better chance of surviving than did fragmented groups. This theory thus suggests an instinctive, immediate, ultimately innate dislike for people who look or seem in some way 'unfamiliar', that is, 'not in the family' (Reynolds 1987:212). Group survival depends on the in-group/out-group division of social reality. The in-group, out-group mechanism works especially well in times of resource scarcity and competition. The ethnocentrism syndrome is directly related to the competitive struggle of groups with incompatible interests. The existence of the out-group covers the ingroup against the risks of internal conflict and aggressiveness. The renowned socio-biologist $\mathrm{O}$ Wilson saw ethnocentrism as the force behind most warlike policies, as well as the irrationally exaggerated allegiance of individuals to their kin and fellow tribesmen (Van Dennen 1987:6). 
Diversity may reflect our reality, but it is not necessarily our choice. Most people are content not to be exposed to the challenge of diversity at all. In this regard Geertz (2000:72) remarks that 'the attraction of "deafness to the appeal of other values"" and of a "relaxand-enjoy-it' approach to one's imprisonment in one's own cultural tradition are increasingly celebrated in social thought. It is an illusion that humanity can wholly free itself from ethnocentrism, or even that we care to do so; it would not be a good thing if we did. Such a 'freedom' would lead to a world, in which cultures, all passionately fond of one another, would aspire only to celebrate one another in such confusion that each would lose any attraction it could have for the others, and its own reason for existing. In other words, humans need diversity and difference with its concomitant emotions and prejudices and this diversity comes with our ethnocentrism. We delude ourselves if we think that equality and fraternity will some day reign among human beings without compromising their social diversity. All true creation implies a certain deafness to the appeal of other values, even going so far as to reject them if not denying them altogether. The alternative is that integral communication with the other eventually spells doom for both his and my creativity (Geertz 2000:70-71). Although this may be true, it remains questionable whether ethnic diversity must be accompanied by ethnic animosity for us to be true to our biological make-up and for us to be culturally creative.

\section{Prejudice as a coping mechanism}

We spent the longest period of our evolutionary past living in small groups ranging from 40 to perhaps 100 members (see Diamond 1998:267-268). To survive, we always had to rely on the group's support as well as on the group's acceptance. For this reason we had to adapt to the group; we had to adopt its modes of behaviour and its value orientations. Today we still tend to define our personal identity to a considerable degree by our membership in groups and by their value orientations. High respect for one's own group implies devaluating other groups, out-groups. Valuating members of other groups lower than they deserve, consepuently serves our interests. This, in turn, leads us into forming various prejudices against other groups. As we all know, these prejudices are sometimes borne out by facts. Group orientation influences behaviour, affect and cognition, all of which can fuel prejudice. The tendency to form prejudices against other groups appears to be biological in origin and remains 
pervasive. It seems difficult to overcome prejudice because of the positively experienced consequences for our 'own' group feeling. We perpetuate our prejudices, because they provide cognitive support and social stability (Flohr 1987:197-198).

Prejudice has strong biological roots, with probable origins in our evolutionary past, serving us as a form of a coping mechanism in a hostile, diverse and challenging environment. For survival purposes, all organisms are equipped with organs, perceptual abilities, instincts, emotions, intelligence with their physiological substrate such as the nervous system, brain and so on. We 'apply' our prejudices in order to cope socially. Our prejudices act in an instinctive way. Lacking a genetically controlled system of orientation similar to the instincts of animals, humans have to rely exclusively on their own cultural inventions. Prejudice is the cultural compensation for our lack of instinctual guidance (Tönnesmann 1987:177). The propensity of the human mind to think in binary terms supports the functioning of prejudices. In order to respond immediately, we intuitively categorise people, ideas and events with the help of our prejudices.

That the human propensity to become attached to groups and the drawing of a sharp line between in-groups and out-groups is the product of evolutionary development sounds very deterministic. From an evolutionary point of view, it makes sense to assume that at least some of the behavioural elements related to the ethnocentric syndrome have become part and parcel of the human behavioural repertoire (Tönnesmann 1987:180). This is not to say that we cannot overcome our natural inclinations. The only solution for the human predicament is that humans will have to reason themselves out of the biological impulses exerting an influence on xenophobia, nationalism, and ethnocentrism (Ike 1987:233-234).

\section{THE CONTRIBUTION OF ETHNOTHEOLOGY (UBUNTU-ETHIC) IN OVERCOMING ETHNOCENTRISM}

The problem with terms such as ethnophilosophy ${ }^{12}$, ethnotheology and ethnoscience is that no theology, science or philosophy can be

12 The idea behind the prefix ethno is that African thought is communal thought. Ethnophilosophy assumes that there is a metaphysical system and an ideology embodied in the traditional wisdom, the institutions and the language of Africa. It believes that the typical African can be filtered out 
explained if there are hundreds of different versions of each. There are hundreds of ethnic groups in Africa, each with its own wisdom and indigenous knowledge systems. Each such knowledge system may have its own theology, philosophy and science, making these systems incommensurable. If we refer to ethnoscience, or ethnotheology, it is assumed that they display general characteristics typical of Africa. This is not to deny that different ethnic groups have different terms, designations and versions of scientific or philosophical topics. The danger is that the identification of general characteristics can be considered reductionist, thus failing to reflect ethnic diversity. This may be African science or philosophy, but it is no longer ethnic science or philosophy ${ }^{13}$.

The success of Western-orientated science and technology was founded on the so-called universality, neutrality and simplicity of its laws, its methods and its rationality. Ethnoscience, in contrast, treats all cognitive systems at par, as belief systems, thereby refusing to acknowledge the epistemological distinction between scientific laws and local belief. This approach may be quite creative and may produce a stimulating variety of 'scientific narratives'. Whether it would be as successful as Western techno-science is a different question. Sandra Harding (1997:45-70) endeavours to support ethnoscience by trying to prove that Western science is ethnocentric as well. She does this by referring to the fact that Western science is influenced by cultural and regional features; that it is not human science but European science; that it is not value-free, but determined by Judeo-Christian belief systems; that Western scientific research focused on European and not African challenges; that power (military objectives) played an important role, and that the science that developed was distinctly European (Harding 1997:51, 52, 55, 61). Without taking issue with these questionable statements, it suffices to indicate that European ethnicity is not to be compared to the ethnic multiplicity we find in Africa.

from African myths, folktales, beliefs, proverbs and languages (Kaphagawani 1998:89).

13 This is supported by (Kaphagawani 1998:91) who mentions authenticity and differences as problems of ethnophilosophy. The problem of difference which distinguishes one African culture from another, calls for specific study of those particular cultures. 
The terms ethnotheology, ethnoscience and ethnophilosophy must represent the multiplicity and diversity of local and ethnic African theologies, indigenous knowledge systems and oral wisdom traditions.

\section{Ethnotheology and African altruism}

Ethnotheology, being a theology of the people for the people in their local context, can contribute to a meaningful multicultural harmony in Africa. The African religious landscape is as diverse as its cultural landscape. African philosophy (especially in the experience-rich wisdom traditions), and African ethnotheology (in the idiom of ubuntu-ethic) can help to overcome destructive ethnocentrism. African ethnotheology, like African ethnophilosophy, is a verb, an activity and not a formal corpus of doctrinal knowledge. The fact that African tradition is still predominantly an oral tradition keeps it alive in everyday life. Ethnotheology is experienced in everyday events.

African culture seems exceptionally altruistic. Ubuntu, being the African version of humanity, displays an altruistic ethic. African altruism follows the biological roots of altruism. Unlike other animals, humans are characterised by world-openness, behavioural plasticity, and imperfect biological equipment. Lacking a genetically controlled system of orientation similar to the instincts of animals, humans have to rely exclusively on cultural inventions such as ubuntu. Both selfishness and altruism are part of human nature. Conflict and cooperation between human beings forms the very core of human sociality, and both have an evolutionary basis. Altruistic behaviour is a biologically explicable phenomenon. If selfish genes programme an organism in such a way that its altruistic acts are directed at conspecifics (your fellow tribesperson) with whom it shares the same genes by descent, then natural selection can favour this behavioural trait. Although maximising one's 'inclusive fitness' by supporting one's kin has been the major solution to the puzzle of altruism, it leaves instances of mutually beneficial cooperation between non-kin unaccounted for. These instances can be explained by the concept of reciprocal altruism, where a non-related recipient of a benefit reciprocates the benefit at a later time. Altruistic impulses, at one time limited to one's kin and to one's own group, might be extended to a wider circle when we realise that we and our kin are one group among others. The scope of moral principles cannot be confined to single groups for two reasons. Firstly, 
everyone (presumably) will be a non-member of some group and, secondly, if conduct is to be seen as regulated only within groups, we still have the possibility of unrestricted hostility and conflict between groups.

Reciprocal altruism is typical of the African ubuntu system (see, for example, the stokvel-custom, Du Toit 2000:33ff). Exemplary here is the way South Africans threat illegal immigrants from Mozambique and Zimbabwe. Although these immigrants pose a threat to local workers (ie more competition for employment opportunities), they are accepted and integrated in community life in townships and squatter camps. If they are repatriated, the police officers guarding these immigrants treat them with respect (in stark contrast to the way the apartheid police treated blacks without pass books). The peaceful transition from apartheid South Africa to democratic South Africa must be ascribed to an ubuntu attitude of solidarity - a triumph for multiculturalism.

\section{The African story}

Culture overlaps, but is not identical with, vibrant community life. Because culture is open to change and exchange, no modern society has a truly unitary culture. A culture is constantly being transformed as its bearers reinterpret the old in the light of new experiences. Attempts to find an essence or 'national soul' are artificial because such attempts try to reduce culture to a code of behaviour (Touraine 2000:165). African culture and polyethnicity should not be limited to some essence. Ubuntu can be seen as the non-essentialist and open meaning of African ethnic identity. This means that ubuntu must be polysemous and vague and active in ethnic sagacity, oral history, rites, rituals and custom of living. African ethnic identity is a narrative identity which comes to the fore in the life stories of the people. Personal identity is embedded in the sense-giving life story that makes up the history of the people. Ethnic tradition and practices have a narrative history which must be known in order to be understood. Ethnotheology is related in different stories. The multi-interpretability of stories in different contexts contributes to the richness of the tradition. Stories unify the significance of a tradition in a meaningful way.

\section{CONCLUSION}

Post-apartheid society acts as a social laboratory in which the multicultural and polyethnic experiment will yield the possibility of 
containing prejudice within acceptable parameters. The fact that white South Africans mandated former President De Klerk to proceed with his reform initiatives demonstrates that prejudice can be contained by values such as justice, human dignity, and human rights. The role of international pressure (sanctions) and the lowscale war obviously contributed towards this transition. Black prejudice in post-apartheid society, as in post-colonial societies, seems to be getting stronger rather than abating. The effect of the TRC hearings was perhaps to amplify black prejudice towards whites rather than to facilitate reconciliation. One can assume that the redistribution of power and the new Constitution helped to change people's prejudices. The government's efforts to instil a culture of dignity, to sell the idea of the rainbow nation, to approve the rights of minorities, to try and address the needs of the poor must also have impacted on prejudices. However, we have enough prejudice remaining to make it necessary that we remain very creative in solving our problems. The best way to change prejudice is by societal interaction and by exposure to difference.

Government has to take multiculturalism and polyethnicity seriously, because no single ethnic group can dominate for too long before uniting other groups against it. The success of the South African experiment spells hope for the rest of Africa, and for the global struggle to maintain multiculturalism. Perhaps the adoption of the ideal of an ubuntu ethic may help us towards this goal, since a culture is only a culture among and through other cultures.

\section{Consulted literature}

Basu, A 1994. The concept of person in African philosophy, $37^{\text {th }}$ annual meeting of the African Studies Association. Toronto.

Basu, A 1998. African philosophy and multicultural thought. Philosophy of education 1-3, www.ed.uiuc.edu

Baudrillard, J 1998. The consumer society. Myths and structures. London: Sage.

Clayton, P 1999. Neuroscience, the person, and God, in Russell J R; Murphy, $\mathrm{N}$; Meyering, T C; Arbib, M A (eds), Neuroscience and the person, 181-214. Vatican City State: Vatican Observatory Publications.

Diamond, J 1998. Guns, germs and steel. London: Vintage.

Dunbar, R I M 1987. Sociobiological explanations and the evolution of ethnocentrism, in Reynolds V; Falger, V; Vine, I (eds), The sociobiology of ethnocentrism, 48-59. London:Croom Helm. 
Du Toit, C W 2000. Roots of violence: Is a common good possible in South Africa, in Du Toit, C W, Truth, violence and prophetic silence. Religion and the quest for a South African common good, 15-41. Pretoria:University of South Africa.

-, C W 2002. Rethinking globalism after September 11: Paradoxes in the evolution of globalisation, in Du Toit, C W \& Lubbe, G J A (eds). After September 11: Globalisation, war and peace, 67-90. Pretoria:University of South Africa.

-, 2003. African Ubuntu and the renewal of human relationships, in Life and the environment. Proceedings of the Third Yoko Civilization international conference. Vol 4, 45-76. Tokyo: Yoko Civilization research institute.

Eze, E C 1993. Rationality and the debates about African philosophy. New York: UMI.

Featherstone, M 1995 Undoing culture. Globalization, postmodernity and identity. London: Sage.

Flohr, H 1987. Biological bases of social prejudices, in Reynolds V; Falger, V; Vine, I (eds), The sociobiology of ethnocentrism, 190-207. London:Croom Helm.

Geertz, C 1973. The interpretation of cultures. New York: Basic Books.

Geertz, C 2000. Available light. Anthropological reflections on philosophical topics. Princeton: University Press.

Gyekye, K 1992. Person and community in African thought, in Wiredu, K \& Gyekye, K (eds). Person and community, 101-122. Washington: The Council for Research in Values and Philosophy.

Harding, S 1997. Is modern science ethnoscience? in Eze, E C (ed). Postcolonial African philosophy, 45-70. Oxford: Blackwell.

Ike, B W 1987. Man's limited sympathy as a consequence of his evolution in small groups, in Reynolds V; Falger, V; Vine, I (eds), The sociobiology of ethnocentrism, 216-234. London:Croom Helm.

Kaphagawani, D N 1998. What is African philosophy? in Coetzee, P H \& Roux A P J (eds) Philosophy from Africa, 86-98. Johannesburg: Thomson.

Louw, D J 2002. Ubuntu and the challenges of multiculturalism in postapartheid South Africa. Utrecht: EZA.

Malherbe, J 1995. African epistemology: Models of rationality (1), in Coetzee, P H \& Van den Berg M E S (eds), An introduction to African philosophy, 223-237. Pretoria: University of South Africa.

Moltmann, J 2002. Science and wisdom. London: SCM.

Reynolds, V 1987. Sociobiology and race relations, in Reynolds V; Falger, V; Vine, I (eds), The sociobiology of ethnocentrism, 208-215. London:Croom Helm. 
Sarpong, P K 1991. Christianity meets traditional African cultures, in Uka E M (ed), Readings in African traditional religion: Structure, meaning, relevance, future, 287-296. New York: Peter Lang.

Silverman, I 1987. Inclusive fitness and ethnocentrism, in Reynolds V; Falger, V; Vine, I (eds), The sociobiology of ethnocentrism, 112-117. London:Croom Helm.

Sogolo, G S 1998. Logic and rationality, in Coetzee P H \& Roux A P J (eds), Philosophy from Africa, 217-233. Halfway House: International Thompson.

Tönnesmann, W 1987. Group identification and political socialisation, in Reynolds V; Falger, V; Vine, I (eds), The sociobiology of ethnocentrism, 175-189. London:Croom Helm.

Touraine, A 2000. Can we live together? Equality and difference. Cambridge: Polity.

Van Dennen, J M G 1987. Ethnocentrism and in-group/out-group differentiation: A review and interpretation of the literature, in Reynolds V; Falger, V; Vine, I (eds), The sociobiology of ethnocentrism, 1-47. London:Croom Helm.

Waghorne, J P 1984. From Geertz' ethnography to an ethnotheology? in Moore, R L \& Reynolds F E (eds), Anthropology and the study of religion, 31-55. Chicago: Centre for the Scientific Study of Religion.

Wilson, E O 1998. Concilience: The unity of knowledge. New York: Vintage,.

Wiredu, K 1992. The moral foundations of an African culture, in Wiredu, K \& Gyekye, K Person and community, 193-206. Washington: The Council for Research in Values and Philosophy. 